\title{
Future applications of apricot (Prunus armeniaca kaisa) B galactosidase in dairy industry
}

\author{
Shakeel Ahmed Ansari ${ }^{1 *}$, Rukhsana Satar ${ }^{2}$, Syed Kashif Zaidi', Mohd Jahir Khan ${ }^{3}$, \\ Muhammad Imran Naseer ${ }^{1}$, Mohammed H Al-Qahtani ${ }^{1}$, Mohamad Yusof Maskat ${ }^{3}$ \\ ${ }^{1}$ King Abdulaziz University, Center of Excellence in Genomic and Medicine Research, Jeddah-21589, Saudi Arabia \\ 2 Ibn Sina National College for Medical Studies, Department of Biochemistry, Jeddah-21418, Saudi Arabia \\ ${ }^{3}$ Universiti Kebangsaan Malaysia, School of Chemical Sciences and Food Technology, Faculty of Science and Technology, \\ 43600 Bangi, Selangor Darul Ehsan, Malaysia \\ *Corresponding author: e-mail: saansari@kau.edu.sa
}

\begin{abstract}
The present study demonstrates the immobilization of $\beta$ galactosidase from apricots (Prunus armeniaca kaisa) on an inexpensive concanavalin A layered cellulose-alginate hybrid gel. Immobilized $\beta$ galactosidase retained $78 \%$ of the initial activity after crosslinking by glutaraldehyde. It exhibited greater fraction of activity at both acidic and basic $\mathrm{pH}$, and showed broad spectrum temperature optimum as compared to free enzyme. Moreover, immobilized enzyme exhibited higher thermal stability at $60^{\circ} \mathrm{C}$ and retained $80 \%$ of the original enzyme activity in presence of $3 \%$ galactose. The crosslinked immobilized enzyme showed improved hydrolysis of lactose from milk and whey in batch processes at $50^{\circ} \mathrm{C}$ as well as in continuous reactors operated at flow rate of $20 \mathrm{~mL} / \mathrm{h}$ and $30 \mathrm{~mL} / \mathrm{h}$ even after one month. Moreover, crosslinked adsorbed $\beta$ galactosidase retained $76 \%$ activity even after its sixth repeated use, thereby promoting its use for lactose hydrolysis in various dairy products even for longer durations.
\end{abstract}

Keywords: Apricots, $\beta$ galactosidase, lactose hydrolysis, dairy industries.

\section{INTRODUCTION}

$\beta$ galactosidase (E.C.3.2.1.23) catalyzes the hydrolysis of lactose into glucose and galactose. This enzyme is widely present in microorganisms, plants and animals and finds its extensive application in food processing industry $^{1}$. Lactose intolerant individuals showed low level of $\beta$ galactosidase in intestine which led difficulty in digesting milk and other dairy products ${ }^{2}$. Thus, the technological importance of the enzyme arises mainly for milk consumption by lactose-intolerant populations, whey disposal and lactose crystallization in frozen concentrated desserts ${ }^{3,4}$.

However, soluble enzymes cannot be used in industries due to product inhibition, instability, non reusability and difficult recovery. In order to overcome such limitations, enzyme immobilization has been considered as one of the best alternatives to use enzymes at large scale in industrial and environmental applications $\mathbf{s}^{\mathbf{5}, \mathbf{6}}$. Immobilized enzymes offered numerous advantages like enhanced stability, easier product recovery, protection of enzymes against inactivating agents and proteolysis ${ }^{7}$. It also prevents enzyme from denaturation and helps to retain the immobilized enzyme in biochemical reactors to further catalyze the subsequent feed and provide more economical use of biocatalysts in industry, waste treatment and in the development of bioprocess monitoring devices like biosensors ${ }^{8-10}$.

$\beta$ galactosidase from various plants and microbial sources has been successfully immobilized for generating lactose free dairy products in the recent past on different matrices by physical adsorption, entrapment, crosslinking and covalent binding ${ }^{11-19}$. These immobilization procedures permit to control the matrix-enzyme interaction for retaining enzymes via different orientations/conditions which remained the key point in increasing their utilization in biotechnological industries significantly.

These studies inspired us to prepare an inexpensive and highly efficient immobilized preparation of Prunus armeniaca kaisa $\beta$ galactosidase on concanavalin A layered calcium alginate-cellulose beads. Effect of various physical and chemical denaturants on the activity of soluble $\beta$ galactosidase ( $\mathrm{S} \beta \mathrm{G}$ ) and crosslinked Con $\mathrm{A}$ layered calcium alginate-cellulose beads adsorbed $\beta$ galactosidase (I $\beta \mathrm{G})$ has been investigated. The effect of product inhibition by galactose on soluble and immobilized $\beta$ galactosidase was monitored. Moreover, soluble and immobilized enzyme has been evaluated for the hydrolysis of lactose from milk and whey in stirred-batch reactors for varying time intervals. Efficiency of I $\beta G$ was examined in continuous reactors for the hydrolysis of lactose at different flow rates. Reusability of immobilized enzyme was also investigated.

\section{MATERIAL AND METHODS}

\section{Material}

Galactose, $\alpha$-methyl- $\beta$-D-glucopyranoside, cellulo$\mathrm{se}$, peroxidase, ethanolamine and p-nitrophenyl $\beta$-D-galactopyranoside (PNGP) and lactose were obtained from Sigma Chem. Co. (St. Louis, MO, USA). Sodium alginate and glutaraldehyde was the product of Koch-Light Lab (Colnbrook, UK). Apricots were purchased from local market. All other chemicals and reagents employed were of analytical grade and were used without further purification.

\section{Partial purification of $\beta$ galactosidase from Prunus armeniaca kaisa}

$\beta$ galactosidase was isolated from Prunus armeniaca kaisa according to the procedure described by Gulzar and $\mathrm{Amin}^{20}$ with slight modifications. The cortical tissue of apricots $(300 \mathrm{~g})$ was homogenized for $10 \mathrm{~min}$ in $0.1 \mathrm{M}$ sodium acetate buffer ( $\mathrm{pH}$ 5.0) and the homogenate was filtered through four layers of cheese cloth. The suspension obtained was stirred on magnetic stirrer for about 4 hours at $4^{\circ} \mathrm{C}$. The residue left after filtration was washed twice by homogenization in the assay buffer. The final residue 
was weighed and brought up to $300 \mathrm{~g}$ with $0.5 \mathrm{M} \mathrm{NaCl}$. This was stirred for $1 \mathrm{~h}$ at $4^{\circ} \mathrm{C}$ and then filtered through Whatman No.1 filter paper. The filtrate was then centrifuged at $10.000 \mathrm{x} g$ on a Remi R-24 cooling centrifuge for $30 \mathrm{~min}$ at $4^{\circ} \mathrm{C}$. The clear supernatant was collected and the precipitate was discarded. After precipitating the supernatant with $80 \%$ ammonium sulphate by overnight stirring, the solution was centrifuged at $10.000 \mathrm{x} g$ for 10 min at $4^{\circ} \mathrm{C}$. The precipitate was decanted and supernatant was again subjected to $0-70 \%$ ammonium sulfate fractionation for about $2 \mathrm{~h}$. The filtrate was finally centrifuged at $10.000 \mathrm{x} g$ for $10 \mathrm{~min}$ at $4^{\circ} \mathrm{C}$. The precipitate collected was re-dissolved in $0.01 \mathrm{M}$ sodium acetate buffer, $\mathrm{pH} 5.0$ and was dialyzed against the assay buffer.

\section{Layering of Con A on calcium alginate-cellulose beads}

Calcium alginate-cellulose beads (500 beads) were incubated overnight with jack bean extract $(25 \mathrm{ml})$ containing Con $\mathrm{A}$ at room temperature with slow stirring on a magnetic stirrer. Con A bound calcium alginate-cellulose beads were washed thrice with $0.1 \mathrm{M}$ sodium acetate buffer, $\mathrm{pH} 5.0$ and stored in the assay buffer for further use.

\section{Crosslinking of $\boldsymbol{\beta}$ galactosidase on Con A layered calcium alginate-cellulose beads}

Con A layered calcium alginate-cellulose beads was incubated with $\beta$ galactosidase $(2000 \mathrm{U})$ overnight at $32^{\circ} \mathrm{C}$ with slow stirring. The unbound enzyme was removed by repeated washing with $0.1 \mathrm{M}$ sodium acetate buffer, $\mathrm{pH}$ 5.0. $\beta$ galactosidase immobilized on the surface of Con A layered calcium alginate-cellulose beads was suspended in $0.1 \mathrm{M}$ sodium acetate buffer, $\mathrm{pH} 5.0$ for $2 \mathrm{~h}$ at $4^{\circ} \mathrm{C}$. The adsorbed enzyme was crosslinked by $0.5 \%(\mathrm{v} / \mathrm{v})$ glutaraldehyde for $2 \mathrm{~h}$ at $4^{\circ} \mathrm{C}$. Finally the beads were incubated with $0.01 \%(\mathrm{v} / \mathrm{v})$ ethanolamine for $90 \mathrm{~min}$ at $30^{\circ} \mathrm{C}$ to stop crosslinking. The integrity of crosslinked immobilized enzyme was examined by incubating beads in 1.0 $\mathrm{M} \alpha$-methyl-D-glucopyranoside for $2 \mathrm{~h}$.

\section{Determination of kinetic parameters}

Kinetic parameters of soluble and immobilized b galactosidase was determined from Line-Weaver Burk plot by measuring their initial rates at varying concentrations of PNPG in $100 \mathrm{mM}$ sodium acetate buffer at pH 5.0.

\section{Effect of $\mathrm{pH}$ and temperature}

Enzyme activity of soluble and immobilized $\beta$ galactosidase preparations $(20 \mu \mathrm{l})$ was assayed in the buffers of different $\mathrm{pH}(\mathrm{pH} 3.0-8.0)$. The used buffers were glycine- $\mathrm{HCl}(3.0)$, sodium acetate $(\mathrm{pH} 4.0-6.0)$ and Tris- $\mathrm{HCl}$ $(7.0,8.0)$. Molarity of the used buffer was $0.1 \mathrm{M}$. The activity expressed at $\mathrm{pH} 5.0$ was considered as control $(100 \%)$ for the calculation of remaining percent activity.

Effect of temperature on soluble and immobilized $\beta$ galactosidase preparations $(20 \mu \mathrm{l})$ was studied by measuring their activity at various temperatures $\left(30-70^{\circ} \mathrm{C}\right)$. The enzyme was incubated at various temperatures in $0.1 \mathrm{M}$ sodium acetate buffer, $\mathrm{pH} 5.0$ for $15 \mathrm{~min}$ and the reaction was stopped by adding $2.0 \mathrm{ml}$ of $2.0 \mathrm{M}$ sodium carbonate solution. The activity obtained at $50^{\circ} \mathrm{C}$ was considered as control $(100 \%)$ for the calculation of remaining percent activity.
Soluble and immobilized $\beta$ galactosidase preparations were incubated at $50^{\circ} \mathrm{C}$ in $0.1 \mathrm{M}$ sodium acetate buffer, $\mathrm{pH} 5.0$ for varying times. Aliquots of each preparation $(20 \mu \mathrm{l})$ were taken out at indicated time intervals and chilled quickly in crushed ice for $5 \mathrm{~min}$. The enzyme was brought at room temperature. The enzyme activity without incubation at $50^{\circ} \mathrm{C}$ was taken as control $(100 \%)$ for the calculation of remaining percent activity.

\section{Effect of galactose}

The effect of galactose $(1.0-5.0 \%, \mathrm{w} / \mathrm{v})$ was measured for $1 \mathrm{~h}$ on the activity of soluble and immobilized $\beta$ galactosidase preparations $(20 \mu \mathrm{l})$ in $0.1 \mathrm{M}$ sodium acetate buffer, pH 5.0. The activity of enzyme without added galactose was considered as control (100\%) for the calculation of remaining percent activity.

\section{Reusability of IßG}

I $\beta \mathrm{G}(20 \mu \mathrm{l})$ was taken in triplicates for assaying the activity of enzyme. After each assay, immobilized enzyme was taken out from assay tubes and was washed and stored in $0.1 \mathrm{M}$ sodium acetate buffer, $\mathrm{pH} 5.0$ overnight at $4^{\circ} \mathrm{C}$ for 6 successive days. The activity determined on the first day was considered as control (100\%) for the calculation of remaining percent activity.

\section{Hydrolysis of lactose from milk and whey by soluble and immobilized $\beta$ galactosidase}

The cold milk was skimmed by centrifugation at $8000 \times g$ for $20 \mathrm{~min}$. The fat layer was removed from milk and stored at $4^{\circ} \mathrm{C}$ for further use. Skimmed milk $(500 \mathrm{~mL})$ was independently treated with soluble and immobilized $\beta$ galactosidase $(125 \mathrm{U})$ in stirred batch process at $40^{\circ} \mathrm{C}$. In the next experiment, skimmed milk was acidified by $\mathrm{HCl}$ until the $\mathrm{pH}$ reaches to 4.8. The casein was removed by centrifugation. Whey $(500 \mathrm{ml})$ was independently treated with soluble and immobilized $\beta$ galactosidase $(250 \mathrm{U})$ in stirred batch process at $40^{\circ} \mathrm{C}$. The aliquot of $250 \mu \mathrm{l}$ was taken out at indicated times for $10 \mathrm{~h}$. The hydrolysis of lactose was estimated by glucose oxidase-peroxidase coupled assay procedure'

\section{Continuous hydrolysis of lactose through the packed- -bed reactors}

Immobilized $\beta$ galactosidase preparations (2000 U) were independently packed in two columns of similar dimensions $(2.0 \times 10.0 \mathrm{~cm})$. The packed volume of each column was $8.0 \mathrm{ml}$. Lactose $(0.1 \mathrm{M})$ dissolved in $0.1 \mathrm{M}$ sodium acetate buffer, $\mathrm{pH} 5.0$ containing $1 \mathrm{mM}$ sodium azide was passed through all the columns at different flow rates at room temperature $\left(30 \pm 2^{\circ} \mathrm{C}\right)$.

\section{Assay of $\boldsymbol{\beta}$ galactosidase}

The hydrolytic activity of $\beta$ galactosidase was determined by measuring the release of $p$-nitrophenol from PNPG at $405 \mathrm{~nm}$. The reaction was performed by continuous shaking in an assay volume of $2.0 \mathrm{ml}$ containing $1.7 \mathrm{ml}$ of $0.1 \mathrm{M}$ sodium acetate buffer, $\mathrm{pH}$ $5.0,0.1 \mathrm{ml} \beta$ galactosidase and $0.2 \mathrm{ml}$ of $20 \mathrm{mM}$ PNPG. The reaction was stopped by adding $2.0 \mathrm{ml}$ of $2.0 \mathrm{M}$ sodium carbonate solution and product ( $p$-nitrophenol) formation was measured spectrophotometrically at 405 $\mathrm{nm}$. One unit (1.0 U) of $\beta$ galactosidase activity is defined as the amount of enzyme that liberates $1.0 \mu$ mole 
of $p$-nitrophenol $\left(\varepsilon_{\mathrm{m}}=4500 \mathrm{~L} / \mathrm{mol} / \mathrm{cm}\right)$ per min under standard assay conditions.

\section{Estimation of protein}

Protein concentration was determined according to the procedure described by Lowry et al., $1951^{18}$. Bovine serum albumin was used as standard.

\section{Statistical analysis}

Each value represents the mean for three independent experiments performed in triplicates, with average standard deviation $<5 \%$. The data expressed in various studies was plotted using Sigma Plot-9 and expressed with standard deviation of error $( \pm)$. Data was analyzed by one-way ANOVA. P-values $<0.05$ were considered statistically significant.

\section{RESULTS AND DISCUSSION}

With the growing expansion of biotechnology industry, it is becoming increasingly evident to design a cheap and novel procedure for obtaining lactose hydrolyzed products at less cost. Moreover, the time consuming and vast complexity involved in preparing immobilization matrix, greater cost of $\beta$ galactosidases and the complicated protocols of their isolation and purification had accounted for nearly $80 \%$ of the total manufacturing cost of immobilized enzymes $^{14,22}$. Therefore, search for inexpensive, simple and applicable immobilized $\beta$ galactosidase led to the isolation of $\beta$ galactosidases from several plant materials for biocatalysis and were found to exhibit wide specificity, easy accessibility and high stability in solution ${ }^{13,16}$.

In the present study, an effort has been made to use an inexpensive and partially purified immobilized $\beta$ galactosidase from Prunus armeniaca kaisa for the hydrolysis of lactose from milk and whey in batch and in continuous reactors. The enzyme adsorbed on Con A layered cellulose-alginate beads retained $82 \%$ of the original activity upon immobilization. However, crosslinking of the adsorbed enzyme with glutaraldehyde resulted in a marginal loss of $4 \%$ enzyme activity (Table 1). It was previously reported by our group that crosslinking Aspergillus oryzae $\beta$ galactosidase on the matrix with glutaraldehyde enhanced its stability by forming strong bonds between enzyme molecules and the matrix ${ }^{1}$. Table 2 suggested that enzyme immobilization resulted in increased $\mathrm{Km}$ and a decrease in Vmax value. When an enzyme was immobilized on glutaraldehyde modified support, $\mathrm{Km}$ of immobilized enzyme increased, while Vmax decreased. This means that the affinity of the enzyme for its substrate and the velocity of enzymatic
Table 2. Kinetic parameters for soluble and immobilized $\beta$ galactosidase. Immobilization of $\beta$ galactosidase on Con A-layered calcium alginate-cellulose beads resulted in increased $\mathrm{Km}$ and a decrease in Vmax value

\begin{tabular}{|l|c|c|}
\hline Enzyme preparation & $\mathrm{Km}[\mathrm{mM}]$ & $\mathrm{Vmax}[\mathrm{mM} / \mathrm{min}]$ \\
\hline Soluble $\beta$ galactosidase & $1.73 \pm 2.4$ & $0.67 \pm 1.7$ \\
\hline Immobilized $\beta$ galactosidase & $1.97 \pm 2.8$ & $0.56 \pm 1.9$ \\
\hline
\end{tabular}

reaction decreased. This was due to the lower accessibility of the substrate to the active site of the immobilized $\beta$ galactosidase and lower transporting of the substrate and products into and out the modified nanomatrix. These observations are in agreement with the Kluyveromyces lactis $\beta$ galactosidase immobilized on surface modified multiwalled carbon nanotubes ${ }^{4}$.

Stability against various denaturing agents is an important factor when selecting an appropriate enzymatic system for any application. Immobilized enzyme showed no change in $\mathrm{pH}$-optima but exhibited remarkable broadening in $\mathrm{pH}$-activity profiles as compared to the native enzyme (Fig. 1). Moreover, the free enzyme showed $74 \%$ activity at $\mathrm{pH} 4.0$ whereas the immobilized $\beta$ galactosidase retained $88 \%$ activity under similar experimental conditions. The temperature-optimum exhibited greater fractions of catalytic activity for the immobilized enzyme as compared to its soluble counterpart (Fig. 2). It was noticed that so-

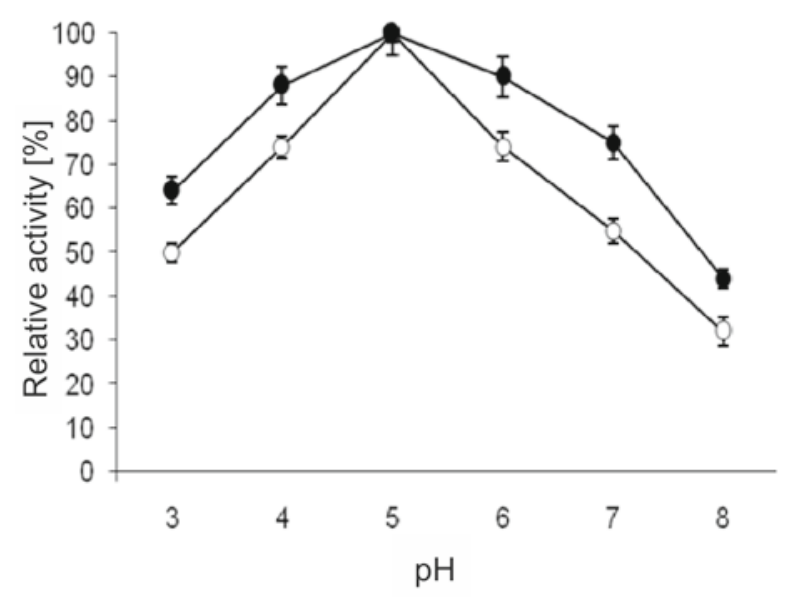

Figure 1. $\mathrm{pH}$ activity profiles for soluble and immobilized $\beta$ galactosidase. The activity of soluble and immobilized $\beta$ galactosidase $(20 \mu \mathrm{l})$ was measured in the buffers of various $\mathrm{pH}(3.0-8.0)$. The buffers used were glycine- $\mathrm{HCl}(\mathrm{pH} 3.0)$, sodium acetate $(\mathrm{pH} 4.0-5.0)$, sodium phosphate (6.0-7.0) and Tris- $\mathrm{HCl}(\mathrm{pH} 8.0)$. Molarity of each buffer was $100 \mathrm{mM}$. The activity at pH 5.0 was taken as control $(100 \%)$ for the calculation of remaining percent activity. The symbols show soluble (๑) and immobilized (○) $\beta$ galactosidase

Table 1. $\beta$ galactosidase immobilized on Con A-layered calcium alginate-cellulose beads. Adsorption of enzyme on Con A layered cellulose-alginate beads retained $82 \%$ of the original activity upon immobilization. This activity was reduced to $78 \%$ as a result of crosslinking by glutaraldehyde

\begin{tabular}{|c|c|c|c|c|c|}
\hline \multirow{2}{*}{ Enzyme preparsation } & \multirow{2}{*}{$\begin{array}{c}\text { Enzyme } \\
\text { activity } \\
\text { loaded } \\
X \\
{[U]}\end{array}$} & \multirow{2}{*}{$\begin{array}{c}\text { Enzyme } \\
\text { activity in } \\
\text { washes } \\
Y \\
{[U]}\end{array}$} & \multicolumn{2}{|c|}{$\begin{array}{l}\text { Activity bound/g of Con A layered } \\
\text { calcium alginate-cellulose beads }\end{array}$} & \multirow{2}{*}{$\begin{array}{c}\text { Activity yield } \\
\text { [\%] } \\
\text { B/A } \times 100\end{array}$} \\
\hline & & & Theoretical $(X-Y)=A$ & Actual $=\mathrm{B}$ & \\
\hline $\begin{array}{l}\text { Enzyme adsorbed on the surface of } \\
\text { beads }\end{array}$ & 1725 & 338 & 1387 & 1138 & $82 \pm 0.93^{*}$ \\
\hline $\begin{array}{l}\text { Enzyme adsorbed on the surface of } \\
\text { beads and crosslinked }\end{array}$ & 1138 & 0 & 1138 & 887 & $78 \pm 0.55 / /$ \\
\hline
\end{tabular}

//P-values $<0.03$ with respect to crosslinked $\beta$ galactosidase* 
luble $\beta$ galactosidase showed $36 \%$ activity at $70^{\circ} \mathrm{C}$ whereas the immobilized enzyme retained $65 \%$ activity at same temperature. Moreover, the soluble enzyme exhibited $34 \%$ and $19 \%$ of enzyme activity after $1 \mathrm{~h}$ and $2 \mathrm{~h}$ exposure at $50^{\circ} \mathrm{C}$ while the immobilized $\beta$ galactosidase retained $74 \%$ and $60 \%$ of the original activity, respectively, under similar incubation conditions (Fig. 3).

Enhanced $\mathrm{pH}$ stability and broad spectrum temperature stability of immobilized enzyme reflected its antithermal property which might be attributed to conformational stability attained by the enzyme as a result of bond formation between enzyme and matrix or lower restriction to substrate diffusion at higher temperatures ${ }^{23}, 24$. However, major problems associated with immobilized enzymes are microbial contamination, protein adherence and channeling. The periodic washing and flow direction of substrate can solve this problem to great extent. The problem of microbial contamination can be solved by exploiting the antithermal property of crosslinked $\beta$ galactosidase ${ }^{7,25}$. Figure 4 shows the inhibitory effect of galactose on the

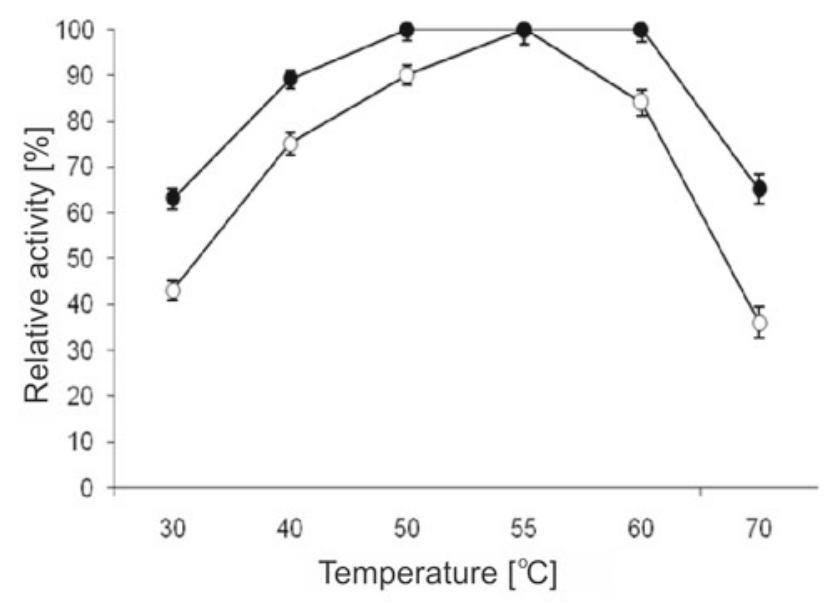

Figure 2. Temperature activity profiles of soluble and immobilized $\beta$ galactosidase. Soluble and immobilized $\beta$ galactosidase $(20 \mu \mathrm{l})$ activity was assayed in $100 \mathrm{mM}$ sodium acetate buffer, $\mathrm{pH} 5.0$ at various temperatures $\left(30-70^{\circ} \mathrm{C}\right)$ for $15 \mathrm{~min}$. The activity obtained at $50^{\circ} \mathrm{C}$ was considered as control $(100 \%)$ for the calculation of remaining percent activity. For symbols, please refer to Figure legends 1

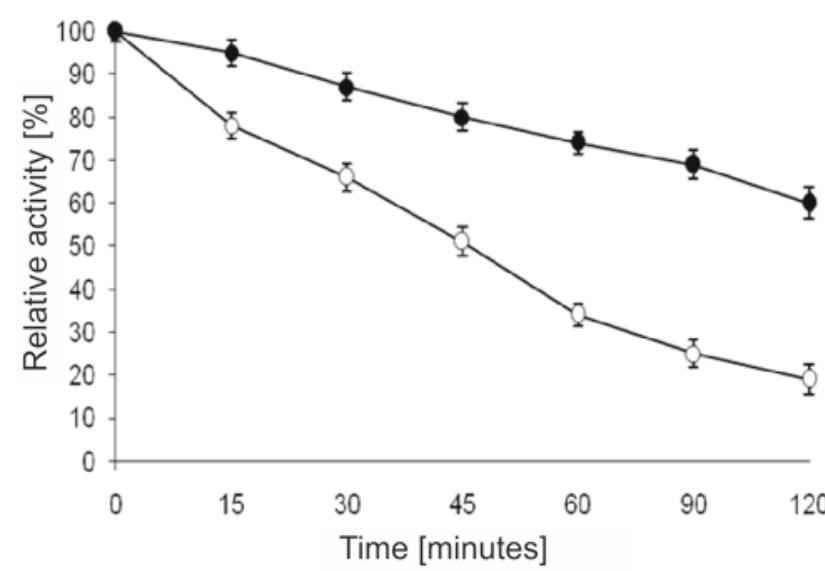

Figure 3. Thermal denaturation of soluble and immobilized $\beta$ galactosidase. Soluble and immobilized $\beta$ galactosidase $(20 \mu \mathrm{l})$ was incubated at $50^{\circ} \mathrm{C}$ in $0.1 \mathrm{M}$ sodium acetate buffer, pH 5.0 for varying times. Aliquots of each preparation were collected at various indicated times and chilled quickly in crushed ice for $5 \mathrm{~min}$. The activity of enzyme without incubation at $50^{\circ} \mathrm{C}$ was taken as control $(100 \%)$ for the calculation of remaining percent activity. For symbols, please refer to Figure legends 1

activity of soluble and immobilized $\beta$ galactosidase. Soluble $\beta$ galactosidase showed $50 \%$ activity in the presence of $3.0 \%$ galactose, while the immobilized enzyme exhibited much higher enzyme activity, $80 \%$ at the same concentration of galactose. Reusability of the immobilized $\beta$ galactosidase has been shown in Figure 5. Immobilized $\beta$ galactosidase showed 82 and $76 \%$ of the initial activity, after its $5^{\text {th }}$ and $6^{\text {th }}$ repeated use, respectively.

Continuous hydrolysis of lactose in batch process exhibited that the rate of hydrolysis was more in case of free enzyme for first few hours as compared to the immobilized enzyme preparations (Table 3). It has been evaluated that lactose hydrolysis in milk by free enzyme was $37 \%$ in $4 \mathrm{~h}$ but the maximum hydrolysis $53 \%$ was achieved in $8 \mathrm{~h}$. Similarly, it was noticed that hydrolysis of lactose in milk by immobilized enzyme was $61 \%$ after $6 \mathrm{~h}$ under identical incubation conditions. The hydrolysis of lactose in whey by free enzyme after $6 \mathrm{~h}$ was $57 \%$ whereas immobilized enzyme hydrolyzed $70 \%$ lactose under similar incubation time. It was due to the fact that soluble

Table 3. Hydrolysis of lactose from milk and whey in batch processes at $50^{\circ} \mathrm{C}$. Rate of hydrolysis was more in case of free enzyme for first few hours as compared to the immobilized enzyme. Moreover, greater percent of lactose was hydrolyzed from whey as compared to milk due to similarity in pH-optima for the apricot $\beta$ galactosidase after greater time intervals

\begin{tabular}{|c|c|c|c|c|}
\hline \multirow{3}{*}{$\begin{array}{l}\text { Time } \\
\text { [h] }\end{array}$} & \multicolumn{4}{|c|}{ Lactose hydrolysis [\%] } \\
\hline & \multicolumn{2}{|c|}{ Milk } & \multicolumn{2}{|c|}{ Whey } \\
\hline & $\mathrm{S} \beta \mathrm{G}$ & $I \beta G$ & $\mathrm{~S} \beta \mathrm{G}$ & $I \beta G$ \\
\hline Control & 0 & 0 & 0 & 0 \\
\hline 1 & $10 \pm 0.25+$ & $8 \pm 0.30^{*}$ & $16 \pm 0.39++$ & $12 \pm 0.18^{* *}$ \\
\hline 2 & $17 \pm 0.35+$ & $20 \pm 0.49^{*}$ & $25 \pm 0.31++$ & $31 \pm 0.52^{* *}$ \\
\hline 3 & $25 \pm 0.11+$ & $36 \pm 0.59^{*}$ & $31 \pm 0.79++$ & $48 \pm 0.47^{* *}$ \\
\hline 4 & $37 \pm 0.65+$ & $51 \pm 0.57^{*}$ & $42 \pm 0.51++$ & $59 \pm 0.39^{* *}$ \\
\hline 5 & $44 \pm 0.49+$ & $55 \pm 0.37^{*}$ & $49 \pm 0.49++$ & $65 \pm 0.49^{* *}$ \\
\hline 6 & $49 \pm 0.73+$ & $61 \pm 0.21^{*}$ & $57 \pm 0.56++$ & $70 \pm 0.19^{* *}$ \\
\hline 7 & $52 \pm 0.56+$ & $65 \pm 0.29^{*}$ & $61 \pm 0.71++$ & $75 \pm 0.73^{\star *}$ \\
\hline 8 & $53 \pm 0.25+$ & $67 \pm 0.47^{*}$ & $69 \pm 0.91++$ & $77 \pm 0.72^{* *}$ \\
\hline 9 & $53 \pm 0.37+$ & $67 \pm 0.28^{*}$ & $69 \pm 0.77++$ & $85 \pm 0.19^{\star *}$ \\
\hline 10 & $53 \pm 0.49+$ & $67 \pm 0.76^{*}$ & $69 \pm 0.38++$ & $85 \pm 0.38^{* *}$ \\
\hline
\end{tabular}

${ }^{*} \mathrm{P}$-values $<0.03$ with respect to soluble $\beta$ galactosidase + ,

${ }^{* *} P$-values $<0.05$ with respect to soluble $\beta$ galactosidase ++ ,

\#P-values $<0.03$ with respect to soluble $\beta$ galactosidase /,

\#\#P-values $<0.05$ with respect to soluble $\beta$ galactosidase//. 


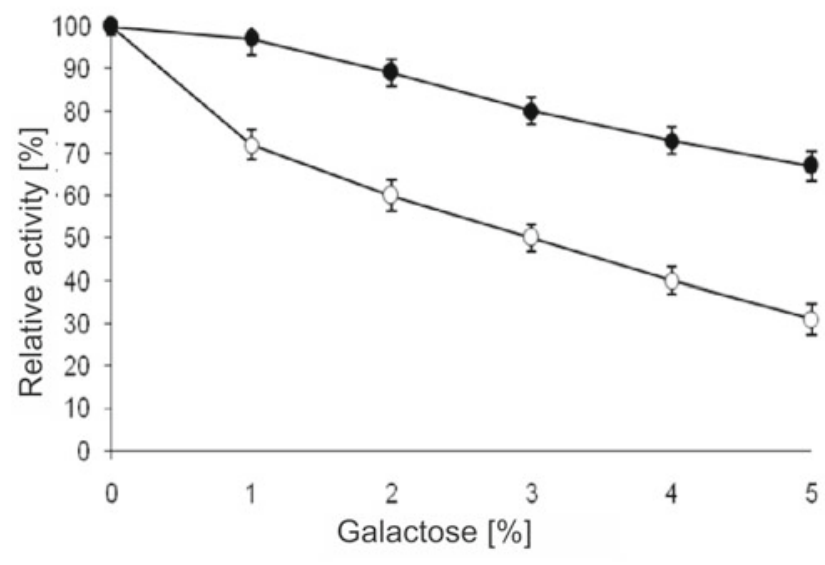

Figure 4. Effect of galactose on soluble and immobilized $\beta$ galactosidase. Effect of increasing concentrations (1.0-5.0\%, $\mathrm{w} / \mathrm{v})$ of galactose on soluble and immobilized $\beta$ galactosidase $(20 \mu \mathrm{l})$ was independently measured in 100 $\mathrm{mM}$ sodium acetate buffer, $\mathrm{pH} 5.0$ for $1 \mathrm{~h}$ at $50^{\circ} \mathrm{C}$. The activity of enzyme without added galactose was considered as control $(100 \%)$ for the calculation of remaining percent activity at various concentrations of galactose. For symbols, please refer to Figure legends 1

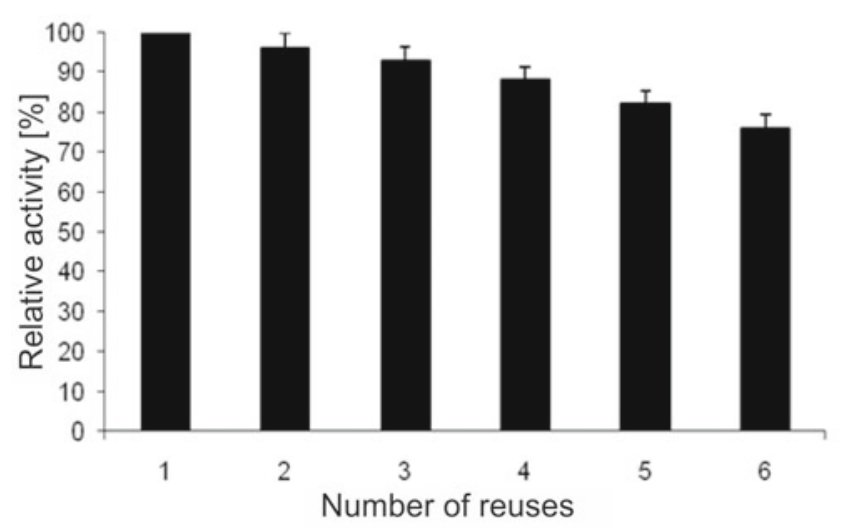

Figure 5. Reusability of immobilized $\beta$ galactosidase. Reusability of crosslinked adsorbed $\beta$ galactosidase was monitored for 6 successive days. The aliquots were taken in triplicates and were assayed for the remaining percent activity. The activity determined on the first day was taken as control $(100 \%)$ for the calculation of remaining activity after each use. For symbols, please refer to Figure legends 1

enzyme was more accessible for hydrolysis of lactose for first few hours but after prolonged time intervals, the rate of lactolysis decreased much faster. This phenomenon of inhibition of $\beta$ galactosidase by the product has been explained earlier by Mammarella and Rubiolo ${ }^{26}$. The rate of lactose hydrolysis in whey and milk depends on the activity of $\beta$ galactosidase, which in turn depends on the reaction conditions like $\mathrm{pH}$, temperature, concentration of enzyme and processing time ${ }^{27}$. Our results indicated higher lactose hydrolysis in whey than in skimmed milk. It was due to the fact that $\mathrm{pH}$ of whey lies in the range of 4.5-5.0 whereas milk has a $\mathrm{pH}$ of $6.5-6.8$. Apricot $\beta$ galactosidase showed its pH-optima at $\mathrm{pH} 5.0$ (Fig. 1), hence it required more enzyme units to hydrolyze milk as compared to whey lactolysis. It has been well documented that plant and fungal $\beta$ galactosidases having acidic $\mathrm{pH}-$ -optima are suitable for processing acid whey and whey permeate whereas the enzymes from yeasts and bacteria
Table 4. Lactose hydrolysis through continuous reactors at different flow rates. Rate of lactolysis decreased as the flow rate was increased. Moreover, the hydrolytic rate achieved at the mentioned flow rates was more due to its greater resistance against product inhibition achieved by glutaraldehyde crosslinking

\begin{tabular}{|l|c|c|}
\hline \multirow{2}{*}{$\begin{array}{l}\text { Number } \\
\text { of days }\end{array}$} & \multicolumn{2}{|c|}{$\begin{array}{c}\text { Lactose hydrolysis }(\%) \\
\text { at flow rate }\end{array}$} \\
\hline Control & $20 \mathrm{~mL} / \mathrm{h}$ & $30 \mathrm{~mL} / \mathrm{h}$ \\
\hline 5 & $100+$ & $100++$ \\
\hline 10 & $98 \pm 0.91^{*}$ & $96 \pm 0.73^{* *}$ \\
\hline 15 & $98 \pm 1.33^{*}$ & $94 \pm 0.95^{\star *}$ \\
\hline 20 & $94 \pm 0.67^{*}$ & $92 \pm 0.96^{* *}$ \\
\hline 25 & $92 \pm 0.88^{*}$ & $92 \pm 1.03^{* *}$ \\
\hline 30 & $90 \pm 1.07^{*}$ & $89 \pm 1.38^{* *}$ \\
\hline${ }^{*} \mathrm{P}<0.05$ with respect to control+ & $85 \pm 1.46^{* *}$ \\
${ }^{* *} \mathrm{P}<0.05$ with respect to control++
\end{tabular}

exhibiting neutral $\mathrm{pH}$-optima are suitable for processing milk. It has been reported earlier that $\beta$ galactosidase from Kluveromyces fragilis hydrolyzes whey permeate containing 5\% lactose into $96 \%$ lactose in $48 \mathrm{~h}$ at $35^{\circ} \mathrm{C}$ and $\mathrm{pH} 7.0^{28}$. Zhou and $\mathrm{Chen}^{11}$ also reported that $\beta$ galactosidase from Kluveromyces lactis immobilized onto the surface of graphite using glutaraldehyde as a crosslinking reagent hydrolyzed 5\% (w/v) lactose to $70 \%$ within $3 \mathrm{~h}$ at $37^{\circ} \mathrm{C}$ but when temperature was increased to $50^{\circ} \mathrm{C}$, only $50 \%$ of lactose was hydrolyzed after $3 \mathrm{~h}$. Moreover, Pisum sativum $\beta$ galactosidase immobilized on chitosan beads also exhibited higher lactose hydrolysis from milk and whey ${ }^{13}$. The reusability study of immobilized enzyme preparations further supported that the enzyme did not leach out of the matrix appreciably (Fig. 5), therefore such preparations could be exploited for the continuous conversion of lactose from milk or whey for longer durations in reactors.

Table 4 shows hydrolysis of lactose by adsorbed and crosslinked $\beta$ galactosidase in continuous packed bed reactors at different flow rates. The greater extent of lactose was hydrolyzed by the column containing crosslinked adsorbed enzyme when the flow rate was $20 \mathrm{~mL} / \mathrm{h}$ while the hydrolytic rates slightly decreased as the flow rate was increased to $30 \mathrm{~mL} / \mathrm{h}$. It was seen that $98 \%$ lactose was hydrolyzed by immobilized enzyme after $10 \mathrm{~d}$ of the operation of reactor when the flow rate was $20 \mathrm{~mL} / \mathrm{h}$. However, immobilized enzyme exhibited 92 and $85 \%$ conversion of lactose after 15 and $30 \mathrm{~d}$ continuous operation of the reactor at a flow rate of $30 \mathrm{~mL} / \mathrm{h}$ (Table 4). It could be attributed to the residence time of lactose inside the column containing immobilized $\beta$ galactosidase ${ }^{26}$. It has been reported earlier that higher lactose hydrolysis took place at lower flow rates. Moreover, the hydrolytic rate achieved at the mentioned flow rates was more due to its greater resistance against product inhibition achieved by glutaraldehyde crosslinking. In view of the stability offered by immobilized enzyme together with its high porosity and excellent flow properties, it appeared to be a useful immobilized matrix that could be exploited for the continuous production of novel dairy products.

\section{CONCLUSIONS}

The present study provides a reasonable basis for applying $\beta$ galactosidase from Prunus armeniaca kaisa in developing 
an effective biotechnological process for preparing lactose free dairy products. Immobilized enzyme exhibited high yield of immobilization and markedly improved stabilization against various physical and chemical denaturants, and significant stabilization against product inhibition by galactose. The use of immobilization technology is of significant importance from economic point of view since it makes reutilization of the enzyme and continuous operation possible and also precludes the need to separate contamination from milk and whey following processing.

\section{ACKNOWLEDGMENTS}

The encouragement and support of Dr. Rukhsana Satar (Senior Lecturer at Ibn Sina National College for Medical Sciences, Saudi Arabia) is gratefully acknowledged while carrying out the experiments and in preparing the manuscript.

\section{LITERATURE CITED}

1. Ansari, S.A. \& Husain, Q. (2012). Lactose hydrolysis from milk/whey in batch and continuous processes by concanavalin A-Celite 545 immobilized Aspergillus oryzae b galactosidase. Food Bioprod. Proc. 90, 351-359. DOI: http://dx.doi.org/10.1016/j. fbp.2011.07.003.

2. Heyman, B. (2006). Lactose intolerance in infants, children and adolescents. Pediatrics 118, 1279-1286. DOI: 10.1542/ peds.2006-1721.

3. Demirhan, E., Apar, D.K. \& Ozbek, B. (2010). A modeling study on hydrolysis of whey lactose and stability of $\beta$ galactosidase. Kor. J. Chem. Eng. 27, 536-545. DOI: 10.1007/ s11814-010-0062-5.

4. Ansari, S.A., Satar, R., Chibber, S. \& Khan, M.J. (2013). Enhanced stability of Kluyveromyces lactis $\beta$ galactosidase immobilized on glutaraldehyde modified multiwalled carbon nanotubes. J. Mol. Cat. B Enz. 97, 258-263. DOI: http://dx.doi. org/10.1016/j.molcatb.2013.09.008.

5. Mateo, C., Palomo, J.M. Fernandez-Lorente, G., Guisan, J.M. \& Fernandez-Lafuent, R. (2007). Improvement of enzyme properties via immobilization techniques. Enzym. Microb. Technol. 40, 1451-1463. DOI: 10.1016/j.enzmictec.2007.01.018.

6. Iyer, P.V. \& Ananthanarayan L. (2008). Enzyme stability and stabilization: Aqueous and non-aqueous environment. Proc. Biochem. 43, 1019-1032. DOI: http://dx.doi.org/10.1016/j. procbio.2008.06.004.

7. Grosova, Z., Rosenberg, M. \& Rebros, M. (2008). Perspectives and applications of immobilized $\beta$ galactosidase in food industry - A review. Czech J. Food Sci. 26, 1-14. DOI: DOI: $10.3109 / 07388550903330497$.

8. Betancor, L., Luckarift, R., Seo, H., Brand, O. \& Spain, JC. (2008). Three-dimensional immobilization of $\beta$ galactosidase on a silicon surface. Biotechnol. Bioeng. 99, 261-267. DOI: 10.1002/bit.21570.

9. Gurdas, S., Gulec, HA. \& Mutlu, M. (2012). Immobilization of Aspergillus oryzae $\beta$ galactosidase onto Duolite A568 resin via simple adsorption mechanism. Food Bioproc. Technol. 5, 904-911. DOI: 10.1007/s11947-010-0384-7.

10. Ansari, S.A. \& Satar, R. (2012). Recombinant $\beta$-galactosidases - Past, present and future: A mini review. J. Mol. Cat. B Enz. 81, 1-6. DOI: http://dx.doi.org/10.1016/j. molcatb.2012.04.012.

11. Zhou, Q.Z.K. \& Chen, X.D. (2001). Immobilization of $\beta$ galactosidase on graphite surface by glutaraldehyde. $J$. Food Eng. 48, 69-74. DOI: http://dx.doi.org/10.1016/S02608774 (00)00147-3.

12. Pessela, B.C.C., Mateo, C., Filho, M., Carrascosa, A. Lafuente, RF. \& Guisan, J.M. (2007). Selective adsorption of large proteins on highly activated IMAC supports in the presence of high imidazole concentrations: Purification, reversible immobilization and stabilization of thermophilic $\alpha$ and $\beta$ galactosidase. Enz. Microb. Technol. 40, 242-248. DOI: 10.1016/j.fct2010.04.016.

13. Diwedi, A. \& Kayastha, A.M. (2009). Stabilization of $\beta$ galactosidase (from peas) by immobilization onto amberlite MB-150 beads and its application in lactose hydrolysis. J. Agric. Food Chem. 57, 682-688. DOI: 10.1021/jf802573j.

14. Rhimi, M., Boisson, A., Dejob, M., Boudebouze, S., Maguin, E., Haser, R. \& Aghajari, N. (2010). Efficient bioconversion of lactose in milk and whey: immobilization and biochemical characterization of $\beta$ galactosidase from the dairy Streptococcus thermophilus LMD9 strain. Res. Microb. 161, 515-525. DOI: 10.1016/j.resmic.2010.04.011.

15. Sun, S., Dong, L., Xu, X. \& Shen, S. (2010). Immobilization of $\beta$ galactosidase from Aspergillus oryzae on macroporous poly GMA newly prepared. Int. J. Chem. 2, 89-96. DOI: $10.1155 / 2011 / 682124$.

16. Ansari, S.A. \& Husain, Q. (2011). Bioaffinity based immobilization of almond (Amygdalus communis) b galactosidase on Con A-layered calcium alginate-cellulose beads: its application in lactose hydrolysis in batch and continuous mode. Iran. J. Biotechnol. 9, 290-301. DOI: 10.4236/ijb.2011.534032.

17. Dwevedi, A., Kumar, A., Singh, D.P., Srivastava, O.N., \& Kayastha, A.M. (2009). Lactose nano-probe optimized using response surface methodology. Biosensors and Bioelectronics 25, 784-790. DOI: 10.1016/j.bios.2009.08.029.

18. Kishore, D. \& Kayastha, A.M. (2012). Optimization of immobilization conditions for chick pea $\beta$-galactosidase $(C p \mathrm{GAL})$ to alkylamine glass using response surface methodology and its applications in lactose hydrolysis. Food Chemistry 134, 1113-1122. DOI:10.1016/j.foodchem.2012.03.055.

19. Kishore, D., Talat, M., Srivastava, O.N. \& Kayastha, A.M. (2012). Immobilization of $\beta$-galactosidase onto functionalized graphene nano-sheets using response surface methodology and its analytical applications towards milk and whey lactose. Plos One 7, e40708. DOI: 10.1371/journal.pone.0040708.

20. Gulzar, S. \& Amin, S. (2012). Kinetic studies on $\beta$-galactosidase isolated from apricots (Prunus armeniaca kaisa). Amer. J. Plant Sc. 3, 636-645. DOI: 10.4236/ajps.2012.35077.

21. Lowry, O.H., Rosenbrough, N.J, Farr, A.L. \& Randall R.J. (1951). Protein measurements with the follin reagent. $J$. Biol. Chem. 193, 265-275. DOI: 10.1021/jf021099r.

22. Zhang, S., Gao, S. \& Gao, G. (2010). Immobilization of $\beta$ galactosidase onto magnetic beads. Appl. Biochem. Biotechnol. 160, 1386-1393. DOI: 10.5539/ijc.v5n4p38.

23. Elnashar, M.M.M. \& Yassin, M.A. (2009). Lactose hydrolysis by $\beta$ galactosidase covalently immobilized to thermally stable biopolymers. Appl. Biochem. Biotechnol. 159, 426-437. DOI: $10.1007 / \mathrm{s} 12010-008-8453-3$.

24. Park, A. \& Oh, D. (2010). Effects of galactose and glucose on the hydrolysis reaction of a thermostable $\beta$ galactosidase from Caldicellulosiruptor saccharolyticus. Appl. Microb. Biotechnol. 85, 1427-1435. DOI: 10.1007/s00253-009-2165-7.

25. Kaur, G., Panesar, PS., Bera, MB. \& Kumar, H. (2009). Hydrolysis of whey lactose using CTAB-permeabilized yeast cells. Bioproc. Biosyst. Eng. 32, 63-67. DOI: 10.1007/s00449008-0221-9.

26. Mammarella, E.J. \& Rubiolo, A.C. (2006). Predicting the packed-bed reactor performance with immobilized microbial lactase. Proc. Biochem. 41, 1627-1636. DOI: 10.1016/j. procbio.2006.03.009.

27. Panesar, R., Panesar, P.S., Singh, R.S., Kennedy, J.F. \& Bera, M.B. (2007). Production of lactose hydrolyzed milk using ethanol permeabilized yeast cells. Food Chem. 101, 786-790. DOI: $10.1016 /$ j.foodchem.2006.02.064.

28. Szczodrak, J. (2000). Hydrolysis of lactose in whey permeate by immobilized $\beta$ galactosidase from Kluveromyces fragilis. J. Mol. Catal. B: Enzym. 10, 631-637. DOI: 10.1016/ S1381-1177(00)00187-9. 